PNL-SA-26071

\title{
WASTE FORMS BASED ON CS-LOADED SILICOTITANATES
}

\author{
M. L. Balmer \\ B. C. Bunker
}

April 1995

Presented at the

The American Ceramic Society - 97th Annual Meeting

\& Exposition

April 30 - May 3, 1995

Cincinnati, Ohio

Prepared for

the U.S. Department of Energy

under Contract DE-AC06-76RLO 1830

\section{Pacific Northwest Laboratory}

Richland, Washington 99352

\section{DISCLAIMER}

This report was prepared as an account of work sponsored by an agency of the United States Government. Neither the United States Government nor any agency thereof, nor any of their employees, makes any warranty, express or implied, or assumes any legal liability or responsibility for the accuracy, completeness, or usefulness of any information, apparatus, product, or process disclosed, or represents that its use would not infringe privately owned rights. Reference herein to any specific commercial product; process, or service by trade name, trademark, manufacturer, or otherwise does not necessarily constitute or imply its endorsement, recommendation, or favoring by the United States Government or any agency thereof. The views and opinions of authors expressed herein do not necessarily state or reflect those of the United States Government or any agency thereof. 


\section{DISCLAIMER}

Portions of this document may be illegible in electronic image products. Images are produced from the best available original document. 


\title{
WASTE FORMS BASED ON Cs-LOADED SILICOTITANATES
}

\author{
M. Lou Balmer and Bruce Bunker \\ Pacific Northwest Laboratory Richland, WA 99352
}

\begin{abstract}
Silicotitanate ion exchange materials are being considered for removal of radioactive $\mathrm{Cs}$ and $\mathrm{Sr}$ from tank wastes at the Hanford site. The phase evolution as a function of heat treatment temperature for several sol gel derived compositions within the $\mathrm{Cs}_{2} \mathrm{O}-\mathrm{SiO}_{2}-\mathrm{TiO}_{2}$ system was investigated, in order to determine if an adequate waste form can be achieved by direct thermal conversion. The $\mathrm{Cs}$ leach rates and Cs loss during heat treatment of select materials were measured. Some compositions which contain large amounts of $\mathrm{Ti}$ melt to form a glass with reasonably low aqueous leach rates. A new Cs-silicotitanate material with a structure isomorphous to pollucite was discovered. This material forms at low temperatures $\left(700-800^{\circ} \mathrm{C}\right)$ where $\mathrm{Cs}$ volatility is negligible. The silicotitanatepollucite exhibits extremely low leach rates $\left(1.42 \mathrm{~g} / \mathrm{m}^{2}\right.$ day $)$ at $90^{\circ} \mathrm{C}$, and has been identified as a promising waste form for Cs containment.
\end{abstract}

\section{INTRODUCTION}

Crystalline silicotitanate (CSTs) ion exchangers, developed by Sandia and Texas A\&M University are promising candidates for removal of $\mathrm{Cs}$ and $\mathrm{Sr}$ from Hanford tank wastes. These exchangers exhibit the highest selectivities for Cs and Sr over $\mathrm{Na}\left(\mathrm{k}_{\mathrm{d}} \approx 10^{5} \mathrm{~mL} / \mathrm{g}\right)$ and have adequate thermal, chemical, and radiation stability.1-3 Because of their potential use in removing Cs from tank waste, CSTs are being evaluated in terms of an overall process flow, leading to the fabrication of solid high level waste (HLW) forms. Two options currently exist for processing Cs-loaded exchangers to produce solid waste forms: 1) elution and concentration, and 2) dissolution in borosilicate waste glass melts. The exchange sites in CSTs retain $\mathrm{Cs}$ even in acidic solution, thus precluding the elution option. For many inorganic ion exchangers, a viable option would be to mix the loaded exchanger with glass frit and other radwaste oxides and dissolve the Cs-loaded ion exchanger directly into borosilicate melts to form a HLW glass. This "melt-dissolution" process has been challenged as a viable option because the perceived maximum allowed $\mathrm{TiO}_{2}$ concentration in current glass formulations is $1 \mathrm{wt} \%$. Assuming ideal column operation can be achieved with a CST, the total HLW glass produced as a result of the CST would increase $33 \%$ over the TWRS reference flowsheet. 3 
This investigation examines the feasibility of alternate glass or ceramic waste forms produced by direct thermal conversion of Cs-loaded silicotitanates. The composition-temperature-phase relationships for the three major constituents of the Cs-loaded exchanger, $\mathrm{Cs}_{2} \mathrm{O}, \mathrm{SiO}_{2}$ and $\mathrm{TiO}_{2}$, is determined. A large body of literature exists on the phase development for several other alkali and alkaline earth silicotitanates $(\mathrm{Na}, \mathrm{K}, \mathrm{Li}, \mathrm{Ca}$ and $\mathrm{Ba}) ; 47$ however, no systematic study of the $\mathrm{Cs}_{2} \mathrm{O}-\mathrm{SiO}_{2}-\mathrm{TiO}_{2}$ ternary has previously been done, and no record of any stable ternary compounds exists.

\section{EXPERIMENTAL PROCEDURE}

Cs-silicotitanate precursor materials with compositions described in Table 1, were synthesized from titanium and silicon alkoxides (tetraisopropyl orthotitanate [TIOT], and tetraethyl orthosilicate [TEOS]) and cesium hydroxide. TEM and EDS showed that a one-step synthesis, where the TEOS and TIOT were mixed then hydrolyzed simultaneously produced a homogeneous, amorphous precursor.

Table I: Cesium Silicotitanate Compositions for Phase Analysis

\begin{tabular}{||c|c|c|c|c|c|c||}
\cline { 2 - 7 } \multicolumn{1}{c|}{} & \multicolumn{2}{c|}{$\mathrm{SiO}_{2}$} & \multicolumn{2}{c|}{$\mathrm{TiO}_{2}$} & \multicolumn{2}{c|}{$\mathrm{Cs}_{2} \mathrm{O}$} \\
& $\mathrm{mol} \%$ & wt\% & mol\% & wt\% & mol\% & wt\% \\
\hline $\mathrm{Cs}_{2} \mathrm{TiSiO}_{5}(1: 1: 1)$ & 33.3 & 14 & 33.3 & 19 & 33.3 & 67 \\
\hline $\mathrm{Cs}_{2} \mathrm{Ti}_{2} \mathrm{Si}_{2} \mathrm{O}_{9}(1: 2: 2)$ & 40 & 21 & 40 & 29 & 20 & 50 \\
\hline $\mathrm{Cs}_{2} \mathrm{TiSi}_{3} \mathrm{O}_{9}(1: 1: 3)$ & 60 & 33 & 20 & 15 & 20 & 52 \\
\hline $\mathrm{Cs}_{2} \mathrm{TiSi}_{5} \mathrm{O}_{13}(1: 1: 5)$ & 72 & 45 & 14 & 12 & 14 & 43 \\
\hline $\mathrm{Cs}_{2} \mathrm{Ti}_{2} \mathrm{SiO}_{7}(1: 2: 1)$ & 25 & 12 & 50 & 32 & 25 & 56 \\
\hline $\mathrm{Cs}_{2} \mathrm{Ti}_{2} \mathrm{Si}_{4} \mathrm{O}_{13}(1: 2: 4)$ & 57 & 36 & 29 & 22 & 14 & 42 \\
\hline
\end{tabular}

Heat treatments were performed at a rate of $5^{\circ} \mathrm{C} / \mathrm{min}$ in air, using approximately $0.5 \mathrm{~g}$ of the dried precursor powder in a platinum crucible. Heat-treated samples were analyzed for the nature and volume fraction of crystalline phases using room temperature XRD. Select samples were analyzed using magic angle spinning nuclear magnetic resonance (MAS NMR), $x$-ray photoelectron spectroscopy (XPS) and TEM.

The Cs leach rate was measured using the MCC -1 standard static leach test. 8 Heat treated pellets were suspended on a teflon string in de-ionized water contained in a teflon container for the leach test. After the desired time at a constant temperature, a sample of the solution, with a known volume, was analyzed for the $\mathrm{Cs}$ content using atomic absorption spectrometry (AAS). For Cs volatility measurements, a Cs-silicotitanate sample, which was either a pellet or powder, was placed in the hot zone in a small pot furnace in a cylindrical, enclosed, platinum $(\mathrm{Pt})$ crucible. The top of the crucible, which extended out of the hot zone, was cooled by convection and acted as a cold finger on which the volatile components were collected. The top and sides of the Pt crucible/cold finger were washed in $0.2 \mathrm{M}$ nitric acid solution. The Cs concentration in the solution was determined by AAS. 


\section{RESULTS AND DISCUSSION}

\section{Phase Selection}

The phase selection, crystallization temperatures, and volume fraction of crystalline phase (as estimated by XRD) as a function of heat treatment temperature for the six silicotitanate precursor materials are summarized in Table 2.

Decomposition and crystallization events were distinguished for each composition by comparing the TGA, DSC, DTA and XRD results. In general, all samples showed the majority of weight loss $(\approx 20 \mathrm{wt} \%)$ by $150^{\circ} \mathrm{C}$, with minor weight losses $(<2 \mathrm{wt} \%)$ up to $500^{\circ} \mathrm{C}$. Crystallization occurred, after the initial weight loss, at a unique temperature for each composition. The phase evolution, relationships between the phases, and some physical properties of each composition are discussed below.

Table II: Phase Selection for Cesium Silicotitanates

\begin{tabular}{|c|c|c|c|c|c|c|}
\hline & \multicolumn{6}{|c|}{ Composition } \\
\hline $\begin{array}{c}\text { Temp. } \\
\left({ }^{\circ} \mathrm{C}\right)\end{array}$ & $(1: 1: 1)$ & $(1: 2: 2)$ & $(1: 1: 3)$ & $(1: 1: 5)$ & $(1: 2: 1)$ & $(1: 2: 4)$ \\
\hline 300 & Amorph. & Amorph. & Amorph. & Amorph. & Amorph. & Amorph. \\
\hline 600 & $\begin{array}{c}\text { Amorph.+ } \\
30 \%(\mathrm{C}+ \\
\mathrm{Cs}_{2} \mathrm{TiO}_{4}^{-} \\
\left.\mathrm{H}_{2} \mathrm{O}\right) \\
\end{array}$ & Amorph. & Amorph. & Amorph. & Amorph. & Amorph. \\
\hline 700 & & $\begin{array}{c}\text { Amorph. }+ \\
15 \% \mathrm{D}\end{array}$ & Amorph. & Amorph. & $\underset{20 \% \mathrm{G}}{\text { Amorph. }}+$ & Amorph. \\
\hline 800 & $\begin{array}{c}\text { Amorph.t } \\
10 \% \\
\mathrm{Cs}_{2} \mathrm{TiO}_{4}{ }^{*} \\
\mathrm{H}_{2} \mathrm{O} \\
\end{array}$ & $\begin{array}{l}60 \% \mathrm{D}+ \\
\text { Amorph. }\end{array}$ & $\begin{array}{l}\text { Amorph. } \\
+20 \% \mathrm{E}\end{array}$ & Amorph. & $\begin{array}{c}\text { Amorph. }+ \\
15 \% \\
\mathrm{Cs}_{2} \mathrm{Ti}_{6} \mathrm{O}_{13}\end{array}$ & $\begin{array}{l}98 \% \text { Polluc.t } \\
\text { Amorph. }\end{array}$ \\
\hline 900 & $\begin{array}{c}\text { Amorph.+ } \\
5 \% \\
\mathrm{Cs}_{2} \mathrm{TiO}_{4}{ }^{\bullet} \\
\mathrm{H}_{2} \mathrm{O} \text { (melt) }\end{array}$ & $\begin{array}{l}\text { 70\% Polluc. } \\
+ \text { Amorph. } \\
\text { (melt) }\end{array}$ & $\begin{array}{l}\text { Amorph. } \\
+20 \% \mathrm{E}\end{array}$ & $\begin{array}{l}\text { Amorph. } \\
\text { (melt) }\end{array}$ & $\begin{array}{c}\text { Amorph. }+ \\
10 \% \\
\mathrm{Cs}_{2} \mathrm{Ti}_{6} \mathrm{O}_{13} \\
\text { (melt) }\end{array}$ & $\begin{array}{c}\text { 98\% Polluc. }+ \\
\text { Amorph. }\end{array}$ \\
\hline 1000 & $\begin{array}{c}\text { Amorph. }+ \\
5 \% \\
\mathrm{Cs}_{2} \mathrm{TiO}_{4} \\
\mathrm{H}_{2} \mathrm{O}\end{array}$ & & $\begin{array}{l}\text { Amorph. } \\
\text { (melt) }\end{array}$ & $\begin{array}{l}\text { Amorph.+ } \\
7 \% \mathrm{~F}\end{array}$ & $\begin{array}{c}\text { Amorph. }+ \\
30 \% \\
\mathrm{Cs}_{2} \mathrm{Ti}_{6} \mathrm{O}_{13}\end{array}$ & $\begin{array}{c}95 \% \text { Polluc. }+ \\
3 \% \mathrm{TiO}_{2}+ \\
\text { Amorph. }\end{array}$ \\
\hline
\end{tabular}

$\mathrm{Cs}_{2} \mathrm{Ti}_{2} \mathrm{Si}_{4} \mathrm{O}_{13}$ and $\mathrm{Cs}_{2} \mathrm{Ti}_{2} \mathrm{Si}_{2} \mathrm{O}_{2}$ (1:2:4 and 1:2:2): The 1:2:2 composition has a sodium analog which forms a single phase material isostructural to the mineral Lorenzenite. ${ }^{4} \mathrm{Cs}_{2} \mathrm{Ti}_{2} \mathrm{Si}_{2} \mathrm{O}_{9}$ does not form a single phase, but rather, crystallizes to a 
metastable, unidentified "Phase D" from 700 to $850^{\circ} \mathrm{C}$, then melts at $900^{\circ} \mathrm{C}$. The melt recrystallizes on cooling to form a phase isostructural to pollucite ( $\mathrm{CsAlSi}_{2} \mathrm{O}_{6}$ ), plus an amorphous material. The metastable phase or phases denoted as phase $\mathrm{D}$ could not be matched to any existing diffraction files and could not be indexed. Because of the complexity of the diffraction pattern, phase $\mathrm{D}$ probably represents two or more metastable crystalline phases. $\mathrm{Cs}_{2} \mathrm{Ti}_{2} \mathrm{Si}_{4} \mathrm{O}_{13}$ remains amorphous until $750^{\circ} \mathrm{C}$, where it begins to crystallize with a structure isomorphous to pollucite ( $\mathrm{CsAlSi}_{2} \mathrm{O}_{6}$ ). By $800^{\circ} \mathrm{C}$ the material is $98 \mathrm{vol} \%$ "pollucite" with a minor amount of residual amorphous phase. After heat treatment to $900^{\circ} \mathrm{C}$, the structure partitions to form $\mathrm{TiO}_{2}(<3$ vol\%), "pollucite", and an amorphous phase. The formation of a phase with the pollucite structure has not been reported for any other alkali or alkaline earth silicotitanates.

The phase selection and partitioning behavior of $\mathrm{Cs}_{2} \mathrm{Ti}_{2} \mathrm{Si}_{4} \mathrm{O}_{13}$ and $\mathrm{Cs}_{2} \mathrm{Ti}_{2} \mathrm{Si}_{2} \mathrm{O}_{9}$ show that $\mathrm{Cs}_{2} \mathrm{Ti}_{2} \mathrm{Si}_{4} \mathrm{O}_{13}$ exists as a stable ternary phase, and that $\mathrm{Cs}_{2} \mathrm{Ti}_{2} \mathrm{Si}_{2} \mathrm{O}_{9}$ lies in a three phase region where $\mathrm{Cs}_{2} \mathrm{Ti}_{2} \mathrm{Si}_{4} \mathrm{O}_{13}$ is one of the terminating phases. Based on the phase selection and EDS results, a likely partitioning scheme for $\mathrm{Cs}_{2} \mathrm{Ti}_{2} \mathrm{Si}_{2} \mathrm{O}_{9}$ would be

$4 \mathrm{Cs}_{2} \mathrm{Ti}_{2} \mathrm{Si}_{2} \mathrm{O}_{9} \rightarrow 2 \mathrm{CsTiSi}_{2} \mathrm{O}_{6.5}$ (poll.) $+\mathrm{Cs}_{2} \mathrm{Ti}_{6} \mathrm{O}_{13}$ (ppt.) $+\left(2 \mathrm{Cs}_{2} \mathrm{O} \cdot 4 \mathrm{SiO}_{2}\right.$ amorph.). The estimated phase regime and partitioning behavior is illustrated in the schematic of a hypothetical phase diagram for $\mathrm{Cs}_{2} \mathrm{O}-\mathrm{TiO}_{2}-\mathrm{SiO}_{2}$ shown in Figure 1. The dark circles represent stable binary ${ }^{9}$, or ternary compounds $\left(\mathrm{Cs}_{2} \mathrm{Ti}_{2} \mathrm{Si}_{4} \mathrm{O}_{13}\right)$, and the light circles are compositions studied in this work.

$\mathrm{Cs}_{2} \mathrm{Ti}_{2} \mathrm{Si}_{4} \mathrm{O}_{13}$, with the pollucite structure, is a new material which represents a possible solution to converting $\mathrm{Cs}-$ loaded silicotitanate ion exchangers to a waste form. The aluminum-bearing pollucite material $\left(\mathrm{CsAlSi}_{2} \mathrm{O}_{6}\right)$ is a zeolite where the Cs is trapped in cages formed by the aluminosilicate network. ${ }^{10}$ Because the Cs is encapsulated in the aluminosilicate cages, pollucite is known to be one of the best materials for Cs containment, exhibiting aqueous leach rates as low as 5.7 $\mathrm{x} 10^{-8} \mathrm{gcm}-2$ day-1.11 The apparent substitution of Ti for $\mathrm{Al}$ in the network, and the presence of $\mathrm{Ti}^{+3}$ rather than $\mathrm{Ti}+4$, represents an unusual coordination and valence for the Ti atom. A powder diffraction simulation program (Micro-POWD, Materials Data Inc.) was used to generate the expected diffraction pattern for the pollucite structure with $\mathrm{Ti}$ atoms in the $\mathrm{Al}+3$ site of $\mathrm{CsAlSi}_{2} \mathrm{O}_{6}$. As shown in Figure 2 , the peak positions and intensities generated by the simulation program are an excellent match to the experimental data. This indicates that significant deviations of $\mathrm{Cs}_{2} \mathrm{Ti}_{2} \mathrm{Si}_{4} \mathrm{O}_{13}$ from the pollucite structure do not exist. ${ }^{133} \mathrm{Cs}$ MAS NMR showed similar spectra for silicotitanate pollucite and the aluminosilicate pollucite, exhibiting one peak with a chemical shift of 3.41 and -7.66 respectively and strong spinning sidebands. X-ray photoelectron spectroscopy (XPS) showed that $\mathrm{Ti}+4$ is the primary valence state, and that $\mathrm{Ti}^{+3}$ may be present in small quantities. More work, including X-ray absorption spectroscopy, Raman spectroscopy, and electron paramagnetic resonance (EPR), is being performed to reveal the local coordination around the $\mathrm{Ti}$ ion and to determine how $\mathrm{Ti}^{+4}$ can be accommodated in the pollucite structure.

$\mathrm{Cs}_{2} \mathrm{Ti}_{2} \mathrm{SiO}_{1}(1: 2: 1):$ This composition partially crystallizes ( $\approx 20$ vol\%) at $700^{\circ} \mathrm{C}$ into an unidentifiable "phase $\mathrm{G}$ " which is similar to $\mathrm{Cs}_{2} \mathrm{Ti}_{6} \mathrm{O}_{13}$. From 800 to 


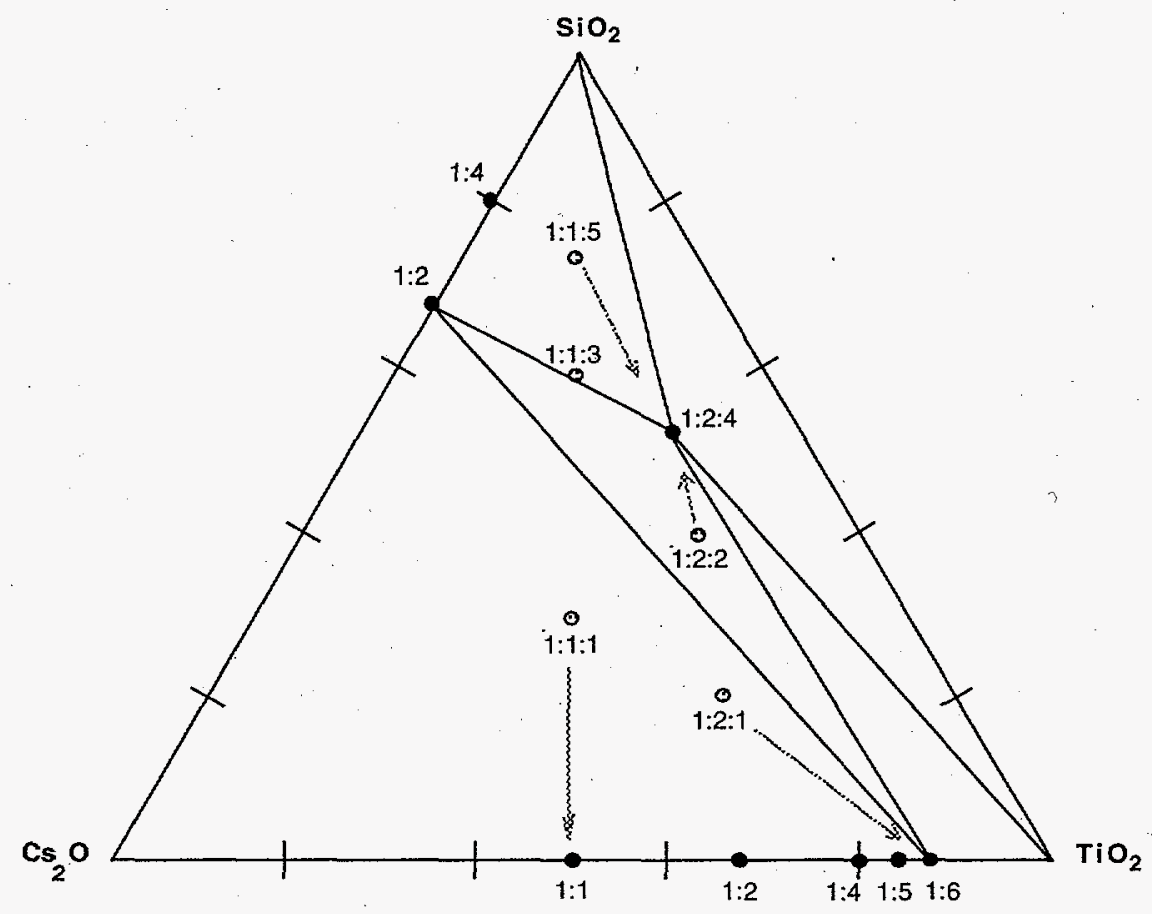

Figure 1. Hypothetical phase diagram based on the preliminary phase selection of $\mathrm{Cs}_{2} \mathrm{O}-\mathrm{TiO}_{2}-\mathrm{SiO}_{2}$. Dark circles represent stable single phase compounds. Light circles are compositions investigated for this study that partition into amorphous and crystalline phases (indicated by the arrows).

$900^{\circ} \mathrm{C}$, the material is primarily an amorphous phase ( 85 to $\left.90 \mathrm{vol} \%\right)$ plus a crystalline phase similar to $\mathrm{Cs}_{2} \mathrm{Ti}_{6} \mathrm{O}_{13}$. Above $900^{\circ} \mathrm{C}$, it melts and precipitates $\mathrm{Cs}_{2} \mathrm{Ti}_{6} \mathrm{O}_{13}(\approx 30 \mathrm{vol} \%)$ on cooling. The following equation represents the phase partitioning behavior, assuming all the $\mathrm{Ti}$ is contained in the crystalline phase:

$$
3 \mathrm{Cs}_{2} \mathrm{Ti}_{2} \mathrm{SiO}_{7} \rightarrow \mathrm{Cs}_{2} \mathrm{Ti}_{6} \mathrm{O}_{13} \text { (crystal.) }+\mathrm{Cs}_{4} \mathrm{Si}_{3} \mathrm{O}_{8} \text { (amph.) }
$$

Because no known stable compounds are represented by the amorphous composition, it is expected to partition into two stable phases after longer times at high temperatures. Due to the large amounts of Cs concentrated in the amorphous phase, this material is likely to have poor resistance to aqueous attack, and thus, would not serve as. an acceptable waste form.

$\mathrm{Cs}_{2} \mathrm{TiSiO}_{5}(1: 1: 1)$ : The 1:1:1 composition forms a stable ternary compound in the lithium, sodium, and calcium silicotitanate systems. $4,5,9$ However, our experiments showed that $\mathrm{Cs}_{2} \mathrm{TiSiO}_{5}$ remains primarily amorphous with small quantities of crystalline $\mathrm{Cs}_{2} \mathrm{TiO}_{4} \cdot \mathrm{H}_{2} \mathrm{O}$ present from $400-1050^{\circ} \mathrm{C}$. A clear glass which contains less than 5 vol\% crystalline $\mathrm{Cs}_{2} \mathrm{TiO}_{4} \cdot \mathrm{H}_{2} \mathrm{O}$ forms after melting at $900^{\circ} \mathrm{C}$. The small amount of $\mathrm{Cs}_{2} \mathrm{TiO}_{4} \cdot \mathrm{H}_{2} \mathrm{O}$ present in the glass drastically effects the stability of the glass, causing it to adsorb water and degrade when exposed to ambient conditions. Therefore, $\mathrm{Cs}_{2} \mathrm{TiSiO}_{5}$, or any composition which contains the $\mathrm{Cs}_{2} \mathrm{TiO}_{4} \bullet \mathrm{H}_{2} \mathrm{O}$ phase, would not be an acceptable waste form. 


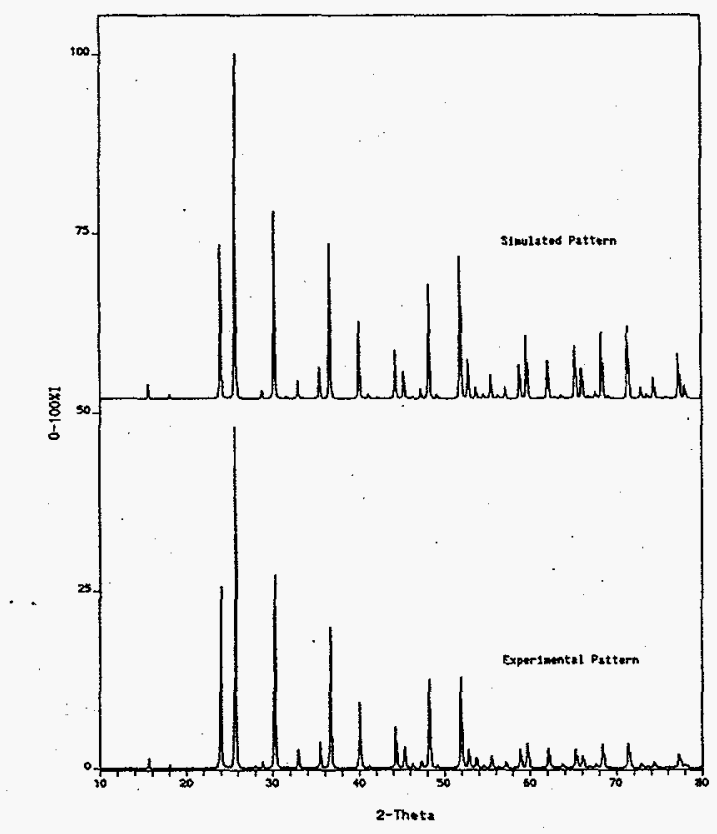

Figure 2. Experimental (lower) and simulated (upper) diffraction patterns for $\mathrm{Cs}_{2} \mathrm{Ti}_{2} \mathrm{Si}_{4} \mathrm{O}_{13}$. The simulated pattern was generated by placing $\mathrm{Ti}$ in $\mathrm{Al}$ sites in pollucite.

$\mathrm{Cs}_{2} \operatorname{TiSi}_{3} \underline{\mathrm{O}}_{2}(1: 1: 3)$ and $\mathrm{Cs}_{2} \operatorname{TiSi}_{5} \mathrm{O}_{13}$ (1:1:5): The 1:1:3 and 1:1:5 compositions both form a clear glass after melting. $\mathrm{Cs}_{2} \mathrm{TiSi}_{3} \mathrm{O}_{9}$ remains amorphous up to $800^{\circ} \mathrm{C}$, where it partially crystallizes $(20 \mathrm{vol} \%)$ into an unidentifiable, metastable phase that is unrelated to any of the phases seen for other cesium silicotitanate compositions. Formation of a glass at this composition indicates that the glass forming regime for cesium silicotitanates is larger than that for sodium. The sodium silicotitanate 1:1:3 composition partitions into two stable crystalline phases, $\mathrm{Na}_{2} \mathrm{TiSi}_{2} \mathrm{O}_{7}(1: 1: 2)$ and $\mathrm{Na}_{2} \mathrm{TiSi}_{4} \mathrm{O}_{11}$ (1:1:4). ${ }^{4}$ The 1:1:3 composition exists as a stable crystalline single phase in the potassium, rubidium, and barium silicotitanate systems. 9

The 1:1:5 composition is the only composition that remained amorphous up to the melting temperature $\left(900^{\circ} \mathrm{C}\right)$. A clear glass, which contains $12 \mathrm{wt} \% \mathrm{TiO}_{2}$ and $43 \mathrm{wt} \% \mathrm{Cs}$, and shows no evidence of any crystalline material, forms after melting. After 1 hour at $1000^{\circ} \mathrm{C}$, a very small amount of material recrystallizes on cooling. Some of the peak positions of the crystalline phase are close to those of pollucite, indicating that this composition lies in a 3-phase regime where pollucite exists as one of the stable crystalline phases. The other phases are likely to be one of the cesium silicates, $\mathrm{Cs}_{2} \mathrm{Si}_{4} \mathrm{O}_{9}$ or $\mathrm{Cs}_{2} \mathrm{Si}_{2} \mathrm{O}_{5}$. Therefore, the overall partitioning scheme is likely to be

$$
2 \mathrm{Cs}_{2} \mathrm{TiSi}_{5} \mathrm{O}_{13} \rightarrow 2 \mathrm{CsTiSi}_{2} \mathrm{O}_{6}+\mathrm{Cs}_{2} \mathrm{Si}_{4} \mathrm{O}_{9}+2 \mathrm{SiO}_{2}
$$

No other alkali or alkaline earth silicotitanates with the 1:1:5 stoichiometry are known to exist as stable single-phase materials. ${ }^{9}$ 


\section{Cs Leach Rate}

The leach rate for $\mathrm{Cs}_{2} \mathrm{Ti}_{2} \mathrm{Si}_{4} \mathrm{O}_{13}$ (silicotitanate pollucite) at $90^{\circ} \mathrm{C}$ and $25^{\circ} \mathrm{C}$ is shown in Figure 3 for various heat treatment temperatures and times. Crystalline $\mathrm{Cs}_{2} \mathrm{Ti}_{2} \mathrm{Si}_{4} \mathrm{O}_{13}$ heat treated to $800^{\circ} \mathrm{C} / 1 \mathrm{hr}$ exhibited a Cs leach rate of $2.29 \mathrm{~g} / \mathrm{m}^{2}$ day at $90^{\circ} \mathrm{C}$ after 24 hours, and of $0.14 \mathrm{~g} / \mathrm{m}^{2}$ day at $25^{\circ} \mathrm{C}$. The $\mathrm{Cs}$ leach rate decayed as a function of $\mathrm{t}^{1 / 2}$, yielding a leach rate after 7 days of $1.17 \mathrm{~g} / \mathrm{m}^{2}$ day and $0.78 \mathrm{~g} / \mathrm{m}^{2}$ day for $90^{\circ} \mathrm{C}$ and $25^{\circ} \mathrm{C}$ samples, respectively. Pre-crystalline $\mathrm{Cs}_{2} \mathrm{Ti}_{2} \mathrm{Si}_{4} \mathrm{O}_{13}$ exhibited a lower 24-hour leach rate than the crystalline material: $1.42 \mathrm{~g} / \mathrm{m}^{2}$ day at $90^{\circ} \mathrm{C}$. This is comparable to $\mathrm{CsAlSi}{ }_{2} \mathrm{O}_{6}$, prepared from metal nitrate solutions and a silica sol heat-treated to $1350^{\circ} \mathrm{C}$, which exhibits leach rates of $1 \mathrm{~g} / \mathrm{m}^{2}$ day at $100^{\circ} \mathrm{C} .12$ Pollucite prepared by hydrothermal hot pressing of Cs with an amorphous aluminosilicate exhibits leach rates of $3.15 \mathrm{~g} / \mathrm{m}^{2}$ day. ${ }^{13}$ Borosilicate waste glass simulant (PNL 76-68) has a $\mathrm{Cs}_{2} \mathrm{O}$ content of $0.99 \mathrm{wt} \%$ and an overall alkali content of $8.41 \mathrm{wt} \%$ as opposed to $42 \mathrm{wt} \% \mathrm{Cs}_{2} \mathrm{O}\left(14 \mathrm{~mol} \%\right.$ ) for $\mathrm{Cs}_{2} \mathrm{Ti}_{2} \mathrm{Si}_{4} \mathrm{O}_{13}$. ${ }^{14}$ The Cs leach rate for PNL 76-68 is estimated by multiplying the bulk leach rate of $\approx 1$ $\mathrm{g} / \mathrm{m}^{2}$ day $\left(90^{\circ} \mathrm{C}\right)$ by the fraction of Cs in the glass to yield $0.01 \mathrm{~g} / \mathrm{m}^{2}$ day. 14,15 In reality, a glass with $42 \mathrm{wt} \% \mathrm{Cs}_{2} \mathrm{O}$ would have a much higher leach rate than that predicted by multiplying the $\mathrm{Cs}_{2} \mathrm{O}$ content by the bulk leach rate $\left(0.42 \mathrm{~g} / \mathrm{m}^{2}\right.$ day $)$. Rana and Douglas measured a leach rate of $8 \mathrm{~g} / \mathrm{m}^{2}$ day at $85^{\circ} \mathrm{C}$ for a silicate glass that contained $15 \mathrm{~mol} \%$ potassium. ${ }^{16}$ From these results, a silicate glass with 14 $\mathrm{mol} \% \mathrm{Cs}_{2} \mathrm{O}$ is estimated to exhibit leach rates of about $10 \mathrm{~g} / \mathrm{m}^{2}$ day, which is several times greater than for the $\mathrm{Cs}_{2} \mathrm{Ti}_{2} \mathrm{Si}_{4} \mathrm{O}_{13}$ at $90^{\circ} \mathrm{C}$.

Minor amounts of amorphous phase in the silicotitanate-pollucite act to increase the $\mathrm{Cs}$ leach rate. $\mathrm{Cs}_{2} \mathrm{Ti}_{2} \mathrm{Si}_{2} \mathrm{O}_{9}$, which is 70 vol\% crystalline pollucite and 30 vol\% amorphous, exhibits leach rates 8 times faster than crystalline pollucite. The leach rate for $\mathrm{Cs}_{2} \mathrm{TiSi}_{5} \mathrm{O}_{13}$ glass heat-treated to $900^{\circ} \mathrm{C} / 1$ hour decays as a function of $\mathrm{t}^{1 / 2}$, exhibiting a rate of $5.6 \mathrm{~g} / \mathrm{m}^{2}$ day after 24 hours and a leach rate of $1.14 \mathrm{~g} / \mathrm{m}^{2}$ day after 7 days. These values are slightly higher than the values for the $700^{\circ} \mathrm{C}$ silicotitanate pollucite but lower than the mixed pollucite glass-ceramic.

The leach rate results show that durability depends on both the thermal history and the composition, and that no universal relationships between the leach resistance and the amount of crystalline or amorphous phase exist. The glass which partitions from $\mathrm{Cs}_{2} \mathrm{Ti}_{2} \mathrm{Si}_{2} \mathrm{O}_{9}$ has poor resistance to aqueous leaching, while the glass formed from $\mathrm{Cs}_{2} \mathrm{TiSi}_{5} \mathrm{O}_{13}$ and the amorphous pre-crystalline phase of $\mathrm{Cs}_{2} \mathrm{Ti}_{2} \mathrm{Si}_{4} \mathrm{O}_{13}$ show good chemical resistance. The chemical durability for each phase or mixture depends on the structure of the crystalline or amorphous material, and the amount of Cs that is contained in either phase.

\section{Cs Volatility}

The weight percent $\mathrm{Cs}$ lost for $\mathrm{Cs}_{2} \mathrm{Ti}_{2} \mathrm{Si}_{4} \mathrm{O}_{13}$ pellets as a function of heat treatment temperature is shown in Figure 4. The losses are extremely low at the expected processing temperatures of 700 to $800^{\circ} \mathrm{C}(0.0022$ to $0.0033 \mathrm{wt} \%)$. For comparison, at the nominal melting temperature of $\approx 1150^{\circ} \mathrm{C}$ for a borosilicate glass, Cs losses can be as high as $70 \mathrm{wt} \% .14$ At $900^{\circ} \mathrm{C}$ losses from borosilicate 
glass are $0.8 \mathrm{wt} \%$ as compared to $0.014 \mathrm{wt} \%$ at $900^{\circ} \mathrm{C}$ for the silicotitanate pollucite. 17 Large increases in surface area for the same weight material $\left(\approx 10^{5}\right)$ produced marginal increases in Cs loss $\left(4 \times 10^{-6} \mathrm{~g}\right)$, whereas a ten-fold increase in total weight produced a much larger increase in Cs loss $\left(37 \times 10^{-6} \mathrm{~g}\right)$.

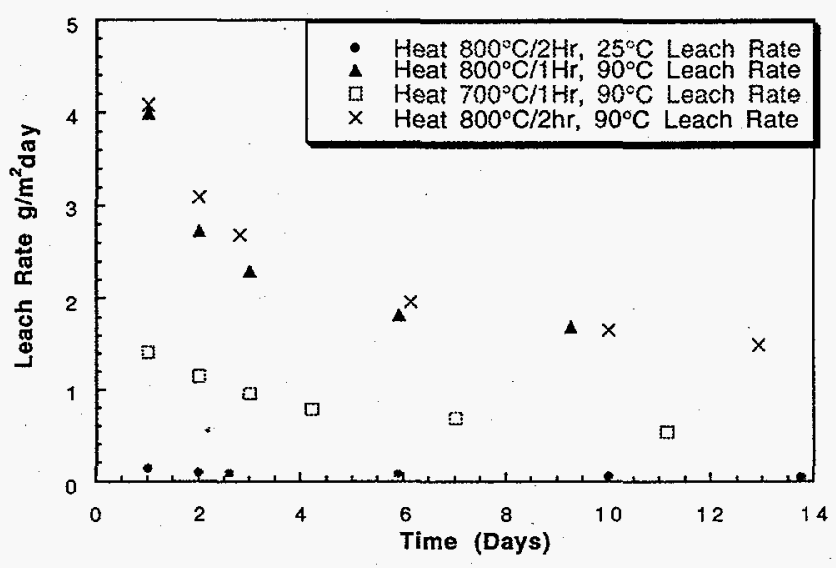

Figure 3. Leach rates at $90^{\circ} \mathrm{C}$ and $25^{\circ} \mathrm{C}$ for $\mathrm{Cs}_{2} \mathrm{Ti}_{2} \mathrm{Si}_{4} \mathrm{O}_{13}(1: 2: 4)$ heat treated at various temperatures and times.

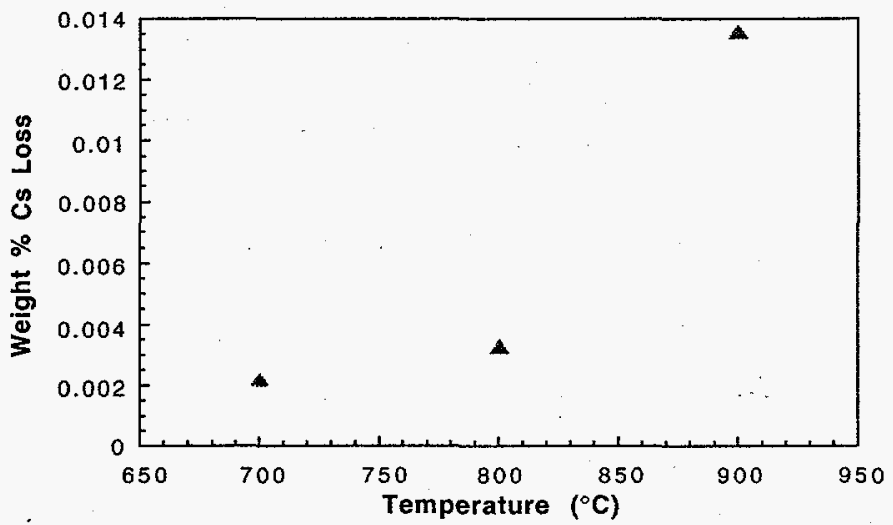

Figure 4. Weight percent Cs loss from $\mathrm{Cs}_{2} \mathrm{Ti}_{2} \mathrm{Si}_{4} \mathrm{O}_{13}(1: 2: 4)$ as a function of heat treatment temperature.

\section{CONCLUSIONS}

The $\mathrm{Cs}_{2} \mathrm{O}-\mathrm{TiO}_{2}-\mathrm{SiO}_{2}$ phase selection studies show that compositions with high $\mathrm{Cs}_{2} \mathrm{O}$ and $\mathrm{TiO}_{2}$ loadings can be directly, thermally converted to durable glass and ceramic materials. The amount of $\mathrm{TiO}_{2}(\leq 22 \mathrm{wt} \%)$ and $\mathrm{Cs}_{2} \mathrm{O}(\leq 52 \mathrm{wt} \%)$ 
incorporated into these glasses and crystalline ceramics far exceeds the limits set for the borosilicate HLW glass. This study showed that the amount of Ti that can dissolve in a glass without sacrificing durability varies depending on the composition and heat treatment conditions. The stable ternary compound, $\mathrm{Cs}_{2} \mathrm{Ti}_{2} \mathrm{Si}_{4} \mathrm{O}_{13}$, with the pollucite structure exhibits very low Cs leach rates, and is a potential waste form for Cs encapsulation. This material represents a new class of Ti-containing zeolites. The compound can be formed by a simple one step heat treatment to $700^{\circ} \mathrm{C}$ to $800^{\circ} \mathrm{C}$, which is well below the current optimal melting temperature of $1150^{\circ} \mathrm{C}$ for borosilicate glass. 18 The ease of processing and low heat treatment temperatures make "direct conversion" a potential alternative to dissolution in a borosilicate glass. At the optimal processing temperature for silicotitanate pollucite, the Cs volatility is negligible; i.e., orders of magnitude lower than the Cs volatility at the melting temperature of a borosilicate glass. The "direct conversion" technique produces waste volumes that are smaller than the volume of the original separations media, and therefore, reduces the volume of $\mathrm{HLW}$ generated as compared to the borosilicate dissolution option.

\section{REFERENCES}

1. B.C. Bunker, "Evaluation of Inorganic Ion Exchangers for Removal of Cs from Tank Wastes," TWRSPP-94-085, Pacific Northwest Laboratory, Richland, WA, September, 1994.

2. R.G. Dosch, N.E. Brown, H.P. Stephens, and R.G. Anthony, "Treatment of Liquid Nuclear Wastes with Advanced Forms of Titanate Ion Exchangers," Waste Management 93, February 28 - March 3, Tucson, Arizona, pp. 17511754.

3. WHC Internal Memo, R.A. Kirkbride to D.J. Washenfelder, "Evaluation of the Impact of the Use of Crystalline Silicotitanate Ion Exchanger on High-Level Waste Glass Production," 9457566, March, 1995.

4. F.P. Glasser, and J. Marr, "Phase Relations in the System $\mathrm{Na}_{2} \mathrm{O}-\mathrm{TiO}_{2}-\mathrm{SiO}_{2}$," J. Am. Cer. Soc., Vol. 62, No. 1-2, pp. 42-47, 1979.

5. R.C. DeVries, R. Roy, and E.F. Osborn, "Phase Equilibria in the System $\mathrm{CaO}-\mathrm{TiO}_{2}-\mathrm{SiO}_{2}$," J. Am. Cer. Soc., Vol. 38, No. 5, pp. 158-171, 1955.

6. D.E. Rase, and R. Roy, "Phase Equilibria in the System $\mathrm{BaTiO}_{3}-\mathrm{SiO}_{2}$,"J. Am. Cer. Soc., 38 [11], pp. 389-395, 1955.

7. F.C. Kracek, N.L. Bowen, and G.W. Morey, "Equilibrium Relations and Factors Inluencing Their Determination in the System $\mathrm{K}_{2} \mathrm{SiO}_{3}-\mathrm{SiO}_{2}$,"J. Phys. Chem., 41, pp. 1183-1193, 1937.

8. D.M. Strachan, R.P. Turcotte, and B.O. Barnes, "MCC-1: A Standard Leach Test for Nuclear Waste Forms,"Nuclear Technology, Vol. 56, pp. 306-312, 1982.

9. Powder Diffraction File, International Center for Diffraction Data, Newton Square PA, 1994.

10. R.M. Beger, "The Crystal Structure and Chemical Composition of Pollucite," Z. Kristallogr., 129, pp. 280-302, 1969.

11. S. Komareni, G.J. McCarthy, and S.A. Gallagher, "Cation Exchange Behavior of Synthetic Cesium Aluminosilicates," Inorg. Nucl. Chem. Letters, 
Vol. 14, pp. 173-177, 1978.

12. E.R. Vance, B.E. Scheetz, M.W. Barnes, and B.J. Bodnar, "Studies of Pollucite," in The Scientific Basis for Nuclear Waste Management, Stephen V. Topp, editor, Elsevier Science Publishing Co. Inc., 1982.

13. K. Yanagisawa, M. Nishoka, and N. Yamasaki, "Immobilization of Cesium into Pollucite Structure by Hydrothermal Hot-Pressing," J. Nuc. Sci. Tech., 24[1], pp 51-60, 1987.

14. L.L. Hench, D.E. Clark, and A.B. Harker, "Review: Nuclear Waste Solids," J. Mat. Sci, Vol. 21, pp. 1457-78, 1986.

15. B. Grambow, and D.M. Strachan, "Leach Testing of Waste Glasses under Near- Saturation Conditions," PNL-SA-11554, 1983.

16. M.A. Rana, and R.W. Douglas, "The Reaction Between Glass and Water. Part I. Experimental Methods and Observations," Phys. and Chem. of Glasses, Vol. 2, No. 6, pp. 179-195, 1961.

17. W.J. Gray, "Volatility of Some Potential High-Level Radioactive Waste Forms", Radioactive Waste Management, Vol. 12, pp. 147-169, 1980.

18. D. F. Bickford, A. Applewhite-Ramsey, C. M. Jantzen, and K. G. Brown, "Control of Radioactive Waste Glass Melters: 1, Preliminary General Limits at Savannah River,” J. Am. Cer. Soc., 73[10], pp 2896-2902, 1990. 